\title{
Electricity Production by Microbial Fuel Cell Using Cheese Whey Wastewater of the Dairy Industry in Rajshahi, Bangladesh
}

\author{
J. Mahato, ${ }^{\mathrm{a}}$ M. Miah, ${ }^{\mathrm{a}}$ M. S. Shovon, ${ }^{\mathrm{a}}$ N. Roy, ${ }^{\mathrm{a}}$ \\ M. S. Easmin, ${ }^{\mathrm{b}}$ and S. C. D. Sharma $\mathrm{a}^{\mathrm{a}, *}$ \\ aDepartment of Biochemistry and Molecular Biology, \\ University of Rajshahi, Rajshahi-6205, Bangladesh \\ ${ }^{b}$ Department of Chemistry, University of Rajshahi, \\ Rajshahi-6205, Bangladesh
}

doi: https://doi.org/10.15255/CABEQ.2021.1922

Original scientific paper Received: January 29, 2021 Accepted: December 2, 2021

Microbial fuel cell is an alternative technology for energy generation aiming to recover chemical energy from biodegradable wastewater to and convert it to electricity. In this study, a small laboratory-scale microbial fuel cell was evaluated to generate electricity using cheese whey wastewater as the sole nutrient source. The open-circuit potential and the stable voltage output with $1000 \Omega$ external resistance of the fuel cell using only cheese whey wastewater as anolyte were $0.925 \mathrm{~V}$ and $0.379 \mathrm{~V}$, respectively. The power density achieved by the cell was $7.18 \mathrm{~mW} \mathrm{~m}^{-2}$, with a maximum current density of $35.75 \mathrm{~mA} \mathrm{~m}^{-2}$. The series connection of seven fuel cells produced the open-circuit potential of $7 \mathrm{~V}$ that could run a $4 \mathrm{~V}$ LED light strip for more than 3 hours. Cheese whey-microbial fuel cell can be considered as a cost-effective renewable energy source for the operation of low energy demanding devices in the future.

Keywords:

cheese whey-microbial fuel cell, cheese whey wastewater, electrogenic activity, electricity production

\section{Introduction}

Since conventional energy sources are being used in every part of our modern day-to-day lives, their existing capacity is expected to reach the peak level in the next decades ${ }^{1}$. Moreover, they release a huge amount of $\mathrm{CO}_{2}$ in the air, which ultimately pollutes the environment and increases the temperature of the Earth ${ }^{2}$. Therefore, many nations are now seeking new energy sources that would less affect global temperature, present no harmful impacts on the environment, and reduce the dependence on fossil fuels ${ }^{3}$. Renewable green energy releases no or very little $\mathrm{CO}_{2}$, and has no negative effect on the environment ${ }^{4}$. Thus, scientists are trying to develop alternative renewable green technologies such as solar $^{5}$, biogas ${ }^{6}$, wind ${ }^{7}$, hydropower ${ }^{8}$, etc.

Microbial fuel cell (MFC) technology is a promising renewable green approach to generate electricity from biodegradable compounds and wastewaters $^{9,10}$. Recently it was shown that MFC is able to produce power with simultaneous removal from wastewater such as domestic wastewater, agricultural wastewater, dairy wastewater, and paper

"Corresponding author: E-mail: subeddev@ru.ac.bd; Tel.: +8801717729849 pulp wastewater ${ }^{11-14}$. MFC can also be used to reduce the organic content of sediment, and improve the quality of rivers and lakes ${ }^{15}$. A typical MFC employs microorganisms as biocatalysts in the anode chamber and produces biofilm on the anode electrode surface ${ }^{16}$. These biofilm-forming microorganisms have the ability to convert the chemical energy of biodegradable matter to electrical power by their bioconversion activities. Microorganisms in the anode chamber use biomass for their growth in anaerobic conditions and generate electrons and protons ${ }^{17}$. Electrons produced by biooxidation are donated to the anode, and then transferred to the cathode via an external circuit. At the same time, protons generated in the anode chamber during the degradation of biomass are transferred to the cathode chamber through proton exchange membrane $\left(\right.$ Nafion-117) ${ }^{18}$. In the cathode chamber, oxidants or chemicals used as catholytes receive electrons and protons; and are consequently reduced to produce water and reduced compounds ${ }^{19-21}$.

Among different kinds of MFC, mediatorless MFCs (ML-MFCs) are commercially more beneficial for energy generation than mediator mediated MFCs (MM-MFCs), because mediators used in the MFC increase the construction and operation expenses, and also may be toxic to the microorgan- 
isms used as biocatalysts in the anode chamber ${ }^{22}$. In contrast, mediators used in the MFC can increase the voltage output and stability of the MFC performance as well as the long-term power supply to devices $^{23,24}$. In this sense, MM-MFCs are more significant than ML-MFCs for large-scale energy production. However, there have been some obstacles behind the large-scale production for both MLMFCs and MM-MFCs. The constructional and operating parameters, such as the choice of substrates (different types of wastewaters) in the anode chamber which are used as nutrients for microbial growth and biocatalytic activities ${ }^{12,25,26}$, characteristics of the electrode materials (electrode types) ${ }^{27,28}$, size of the electrodes ${ }^{29}$, type of membrane or separator ${ }^{30,31}$, temperature ${ }^{32}, \mathrm{pH}^{33}$ and conductivity ${ }^{34}$ affect the performance and stability of the MFC. Variations in temperature usually affect the system kinetics, mass transfer, and distribution of microbial community in bioanode. However, changes in $\mathrm{pH}$ and conductivity can affect the proton transfer rate and internal cell resistance resulting in the alteration of MFC performance. Moreover, the variation of oxidants used in the cathode can also influence the voltage output of the MFC. For example, $\mathrm{KMnO}_{4}$ solution in the cathode chamber produces higher potential than other oxidants used as catholyte ${ }^{20,35}$. The biofilm formed on the anode electrode surface and on separator can hamper substrates diffusion to the catalytic sites, and consequently affect the MFC performance by altering the rate of electron and proton production as well as their transfer ${ }^{36}$. Thus, in order to obtain the highest performance of a MFC, optimization is an essential task. Neural network method can help to optimize the electrochemical parameters such as the type of wastewater, electrode material, $\mathrm{pH}$, conductivity, etc., for good MFC performance ${ }^{37}$.

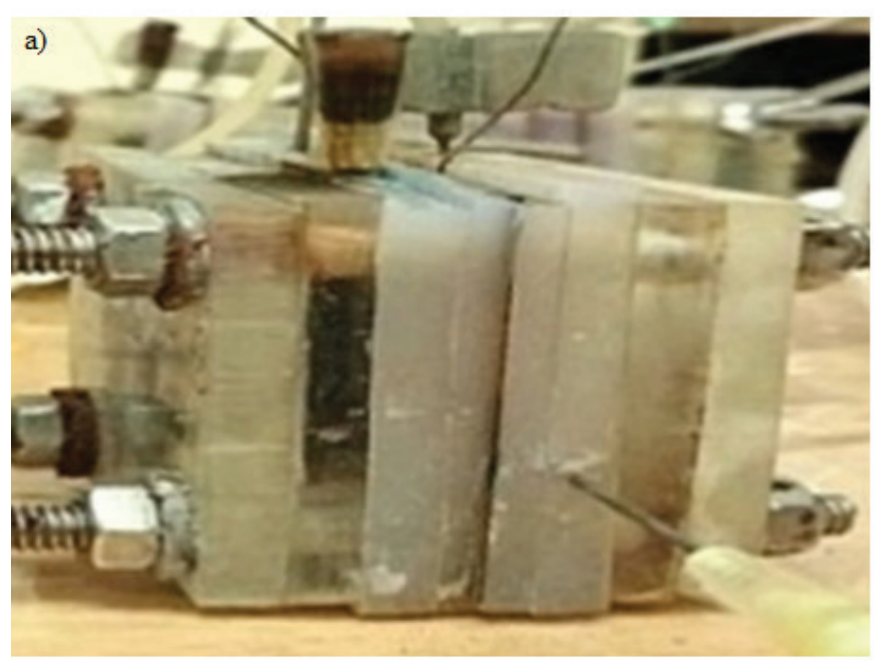

Although there are various types of wastewaters or biodegrading compounds in the environment, cheese whey wastewater is ideal because it contains all nutrients for the growth of microorganisms. Cheese whey wastewater can be used as a cost-effective nutrient source for electricity generation by MFC as it is easily available and discarded in large amounts every day from the dairy industry into the drainage system. Cheese whey represents about 85 $-95 \%$ of milk volume and contains about $55 \%$ of milk nutrients in the amount of $4.5-5 \%(\mathrm{w} / \mathrm{v})$ lactose, $0.6-0.8 \%(\mathrm{w} / \mathrm{v})$ soluble proteins, $0.4-0.5 \%$ $(\mathrm{w} / \mathrm{v})$ lipids and $8-10 \%(\mathrm{w} / \mathrm{w})$ mineral salts ${ }^{38}$. Cheese whey wastewater also possesses small amounts of lactic acid, citric acid, urea, and B-vita$\operatorname{mins}^{39,40}$.

The present work was designed to construct small-size two-chambered (each chamber contains $10 \mathrm{ml}$ solution) mediator-less cheese whey MFC (CW-MFC) for electricity production from cheese whey wastewater (CWW) collected from the local dairy industry in Rajshahi city corporation area, Rajshahi, Bangladesh. The study also investigates the influence of mediator resazurin on the performance of MFC. For the optimization of the mediator-less CW-MFC, the effect of various factors such as oxidants, electrode surface area, nitrogen and carbon sources on power generation were evaluated.

\section{Materials and methods}

\section{MFC construction}

Each two-chambered MFC (Fig. 1) was constructed using polycarbonate and rubber blocks with well-defined holes (each hole was $3.0 \mathrm{~cm}$ in diameter) having a capacity of $10 \mathrm{~mL}$ solution in each

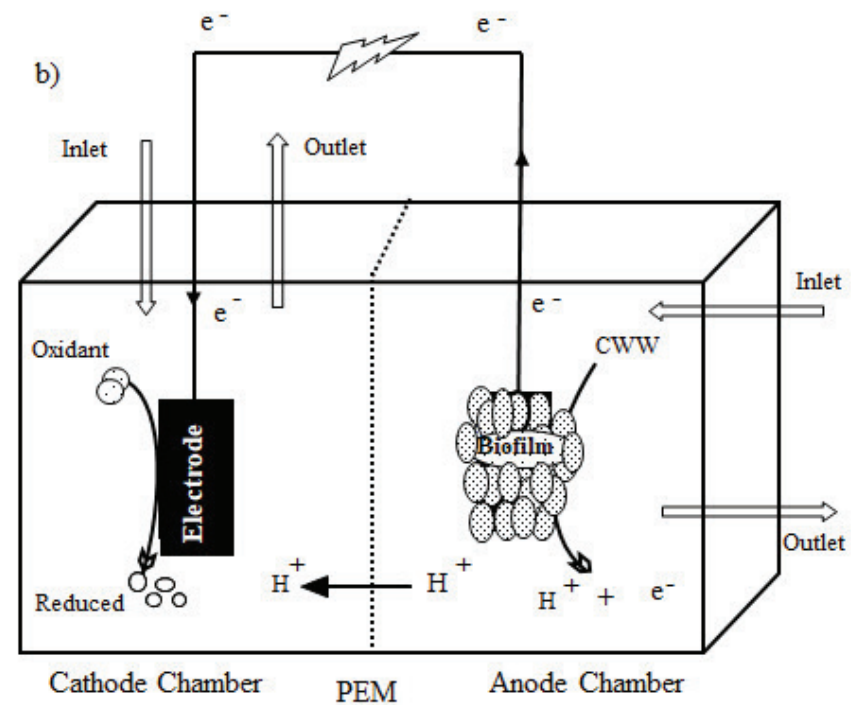

Fig. 1 - Experimental setup of the CW-MFC in laboratory (a), and the schematic diagram of the CW-MFC (b) 
chamber. Proton exchange membrane (PEM, Nafion-17) was used as a separator between anode and cathode chambers. Prior to use, Nafion-17 was soaked sequentially in $30 \% \mathrm{H}_{2} \mathrm{O}_{2}$, deionized $\mathrm{H}_{2} \mathrm{O}$, $0.5 \mathrm{M} \mathrm{H}_{2} \mathrm{SO}_{4}$, and deionized $\mathrm{H}_{2} \mathrm{O}$ (soaking time of 1 hour for each step). Carbon felts of $2 \mathrm{~cm}^{2}$ surface area were used as both anode and cathode electrodes. The electrodes were connected by $\mathrm{Ti}$ wire with an external resistor.

\section{MFC operation}

After constructing a two-chambered MFC and inserting electrodes in each chamber, the anode chamber was filled with locally collected cheese whey wastewater (CWW) from the dairy industry in Rajshahi city corporation area, Rajshahi, Bangladesh. The anode chamber was then inoculated with a preacclimatized suspension of inoculums collected from cheese whey wastewater under anaerobic conditions. The cathode chamber of the reactor was filled with a buffer solution or different oxidizing agents (phosphate buffer, $\mathrm{KMnO}_{4}, \mathrm{~K}_{3} \mathrm{Fe}(\mathrm{CN})_{6}$, and $\mathrm{K}_{2} \mathrm{Cr}_{2} \mathrm{O}_{7}$ ). The $\mathrm{pH}$, total dissolved solids (TDS), and conductivity of the anode solution were $6.04 \pm 0.04$, $5.05 \pm 0.03 \mathrm{~g} \mathrm{~L}^{-1}$, and $13.00 \pm 1.00 \mathrm{mS} \mathrm{cm}^{-1}$, respectively, while the $\mathrm{pH}$ of the cathode solution was $7.04 \pm 0.05$. The CW-MFC was operated under open and closed circuits with $1000 \Omega$ at room temperature using anaerobic cheese whey wastewater as anolyte and oxidant as catholyte, unless otherwise stated. The anode and cathode solutions were replaced when the voltage output dropped to a lower level. To construct a polarization curve, the CWMFC was first operated in open circuit conditions, and then connected after attaining stable open circuit potential with varying external resistance $(10000 \Omega-10 \Omega)$. For each external resistance, the voltage output was recorded once the potential had reached a stable state. A series of experiments was also conducted to investigate the performance of the two-chambered CW-MFC for electricity generation modulating various parameters.

\section{Electrochemical measurement}

The voltage $(V)$ output is measured by a digital multimeter (Vector VC830L), and recorded at 5-minute intervals. The $\mathrm{pH}$ and conductivity of the anolyte and catholyte were measured with a $\mathrm{pH}$ meter (Adwa, China) and conductivity meter (Adwa, China), respectively. The voltage $(V)$ was converted to current $(I)$, and power $(P)$, according to $I=V / R$ and $P=V^{2} / R$, respectively, where $R$ is the external resistance. The current and power densities were calculated by dividing the current and power by surface area $(A)$ of anode.

\section{Results and discussion}

\section{CW-MFC performance}

The performance of the CW-MFC was evaluated by operating a MFC with CWW as an anolyte without the addition of substrates or vitamin and mineral solutions. During operation, initially, mediator-less CW-MFC showed very low voltage output from the first to the third batch of the fed-batch experiment. The voltage output generated by the CWMFC gradually increased with increasing batch numbers. After several batch experiments, the CWMFC produced a noticeable voltage as a result of the maturation period of anodic biofilm. The gradual increment of voltage output with time was due to the increase in the number of bacterial cells in the biofilm and the efficient metabolic activity of electrogenic bacteria ${ }^{41}$.

The anolyte and catholyte of the CW-MFC were changed every two days for the first four batches (due to the reduced or slower performance of the CW-MFC), but after the fourth batch, the operating times gradually decreased, which was attributed to the increasing number of bacterial cells on the anodic biofilm. A large number of bacterial cells can utilize the substrate faster. In addition, the exo-electrogenic bacteria of biofilm produces a huge number of protons that are transferred to the cathode chamber, and facilitate the reduction of oxidant or electron acceptor by electrons coming from the anode through the external circuit. During steady state, bacterial biofilm is matured, and the bacterial cells achieve their efficient potential to transfer electrons to the anode, thus increasing the

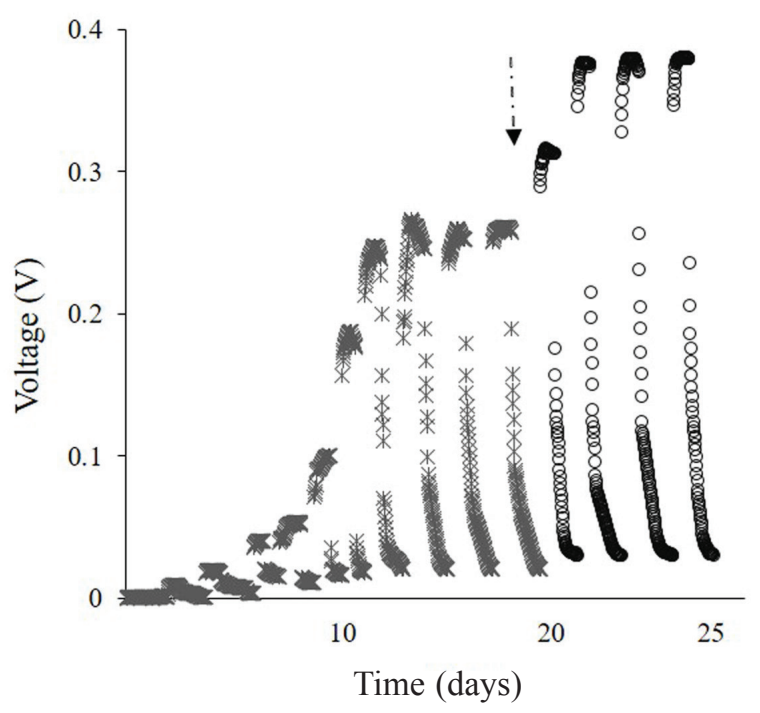

Fig. 2 - Voltage output of the CW-MFC at $1000 \Omega$ in fed batch experiment with phosphate buffer (light black star), and potassium permanganate (black round) as catholytes. Arrow indicates the replacement of catholyte. 
electron transfer rate via an outer circuit to the cathode, resulting in maximum power generation. After the eighth batch, the CW-MFC exhibited high voltage production, and the performance remained stable during the subsequent batches. At the stable stage, the highest voltage generated by the CWMFC using CWW as an anolyte and $100 \mathrm{mM}$ phosphate buffer solution with oxygen purging as catholyte was approximately $0.260 \mathrm{~V}$ with a fixed $1000 \Omega$ external resistance. This result is consistent with the previous report that obtained a voltage output of $0.23 \mathrm{~V}$ using diluted cheese whey wastewater in a two-chambered $\mathrm{MFC}^{42}$. After attaining stable voltage, the phosphate buffer was replaced with $6.3 \mathrm{mM}$ potassium permanganate as catholyte, and the performance of the CW-MFC with external resistance $(1000 \Omega)$ improved, and the highest voltage output of $0.379 \mathrm{~V}$ was obtained (Fig. 2).

\section{Effect of different oxidants on CW-MFC performance}

Phosphate buffer supplied with oxygen $\left(\mathrm{O}_{2}\right)$ and other chemicals were used as oxidants or electron acceptors in the cathode chamber to examine the rate of electron transfer by oxidants for better MFC performance. The study has shown that $\mathrm{KMnO}_{4}$ used in the cathode chamber as an electron acceptor had better electron receiving capability than other oxidants. The maximum open-circuit potential (OCP) after one-hour operation and the closed-circuit voltage with $1000 \Omega$ obtained by the CW-MFC for $6.3 \mathrm{mM} \mathrm{KMnO}_{4}$ were $0.925 \mathrm{~V}$ and $0.379 \mathrm{~V}$, respectively. The order of oxidants in MFC performance was $\mathrm{KMnO}_{4}>\mathrm{K}_{2} \mathrm{Cr}_{2} \mathrm{O}_{7}>\mathrm{K}_{3} \mathrm{Fe}(\mathrm{CN})_{6}>$ oxygen $\left(\mathrm{O}_{2}\right)$ in phosphate buffer with the output voltages of $0.379 \mathrm{~V}, 0.323 \mathrm{~V}, 0.307 \mathrm{~V}$ and $0.266 \mathrm{~V}$, respectively (Fig. 3a); and with the open-circuit voltages of $0.925 \mathrm{~V}, 0.80 \mathrm{~V}, 0.72$ and $0.70 \mathrm{~V}$, respectively (Fig. 3b).

In a two-chambered MFC, oxidants used in the cathode chamber receive protons and electrons through PEM and external circuit, respectively, and are converted into their reduced forms, hence producing continuous current flow. From the evaluation of various electron acceptors, it was observed that the performance of the CW-MFC depended on the efficiency of the oxidants used in the cathode chamber. The OCPs of the CW-MFCs obtained in this study are in agreement with the results reported by Kong et al., 2010, in that the OCPs of $1.132 \mathrm{~V}$, $0.764 \mathrm{~V}$, and $0.438 \mathrm{~V}$ were obtained with $\mathrm{KMnO}_{4}$, $\mathrm{K}_{3} \mathrm{Fe}(\mathrm{CN})_{6}$, and dissolved oxygen $\left(\mathrm{O}_{2}\right)$, respective$1 y^{43}$. A similar result was also observed in a previous study, that obtained maximum OCP of $1.04 \mathrm{~V}$, when $\mathrm{KMnO}_{4}$ was used as catholyte compared to $\mathrm{K}_{3} \mathrm{Fe}(\mathrm{CN})_{6}(\mathrm{OCP}, 0.71 \mathrm{~V})$ and $\mathrm{K}_{2} \mathrm{Cr}_{2} \mathrm{O}_{7}$ (OCP, $0.56 \mathrm{~V})^{44}$. Another report explained that the steady- state voltage with $\mathrm{KMnO}_{4}$ as a cathode electron acceptor was $45 \mathrm{mV}$, while the steady-state voltage for $\mathrm{K}_{3} \mathrm{Fe}(\mathrm{CN})_{6}$ was $22 \mathrm{mV}^{45}$. The variation in the amount of energy generated by MFCs with various oxidants among different studies is due to the use of various electrodes, anolytes and the concentration of cathodic oxidants. However, potassium permanganate as cathode electron acceptor showed higher catalytic activity than other oxidants in all studies.

The result of this study suggests that potassium permanganate can be a good choice as catholyte for the enhancement of electricity production by $\mathrm{CW}$ MFC. A large number of protons generated by the bio-anode of the CW-MFC may help to maintain cathodic $\mathrm{pH}$ around 7.0 for the stability of maximum catalytic activity of potassium permanganate $^{46}$
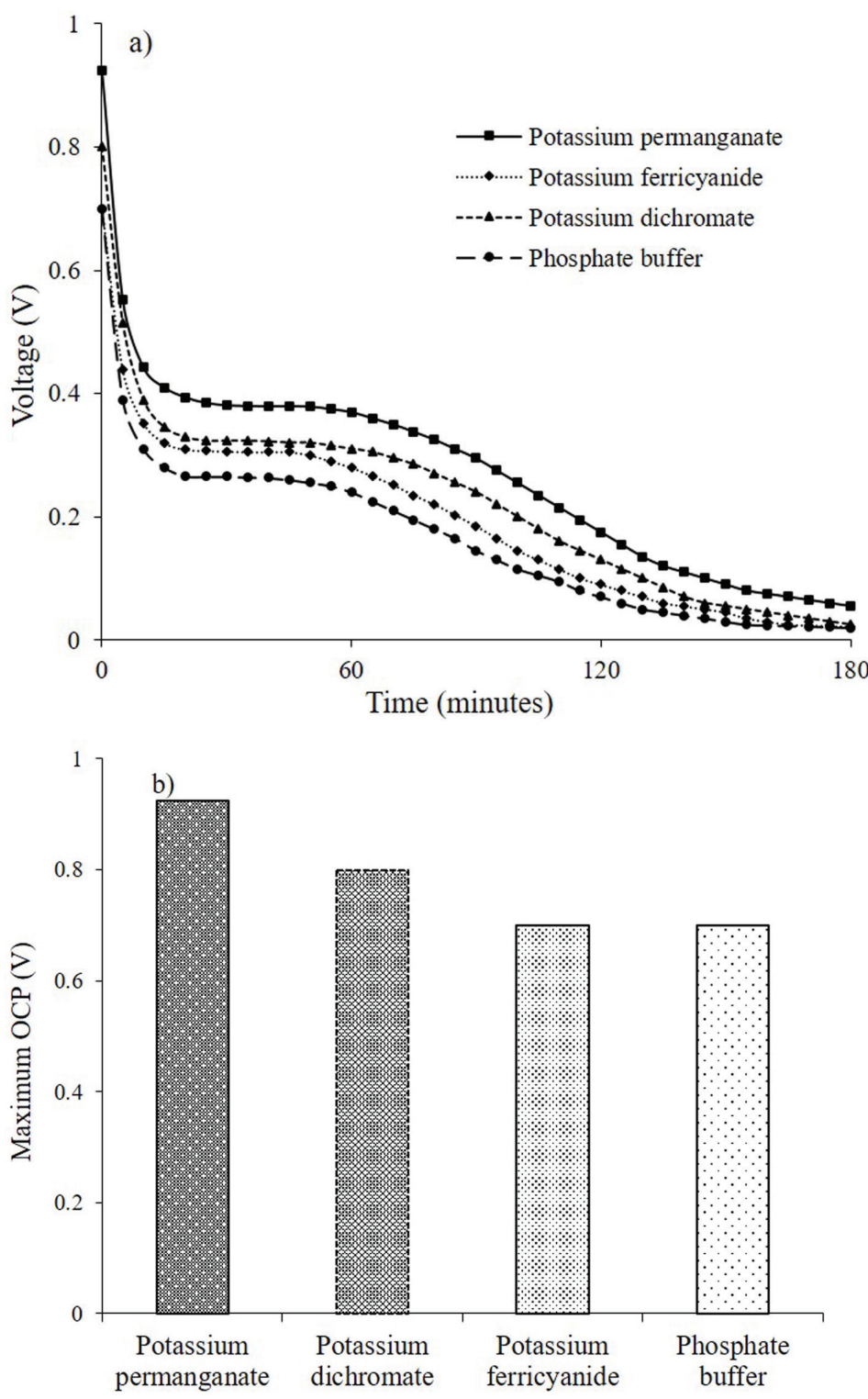

Fig. 3 - Voltage outputs (a), and open-circuit potentials (b) of the CW-MFCs with different oxidants as catholytes 


\section{Effect of mediator on CW-MFC performance}

To evaluate the positive effect of redox mediator on the CW-MFC performance, $10 \mu \mathrm{L}$ of $1 \mathrm{~g} \mathrm{~L}^{-1}$ resazurin was introduced into the anode chamber during operation. The electricity generation increased when resazurin was used with CWW as anolyte and potassium permanganate as catholyte. The maximum voltage output of the resazurin-mediated CW-MFC was $0.414 \mathrm{~V}$ (Fig. 4a); and the voltage dropout rate slowed down and consequently increased the voltage dropout time compared to the non-mediator CW-MFC. Moreover, the OCP increased when resazurin mediator was used with $\mathrm{CWW}$ in the anode chamber (a maximum OCP of 0.985 V) (Fig. 4b), which was higher than the CWMFC without resazurin mediator. The main impact of the mediator is that it facilitates the electron
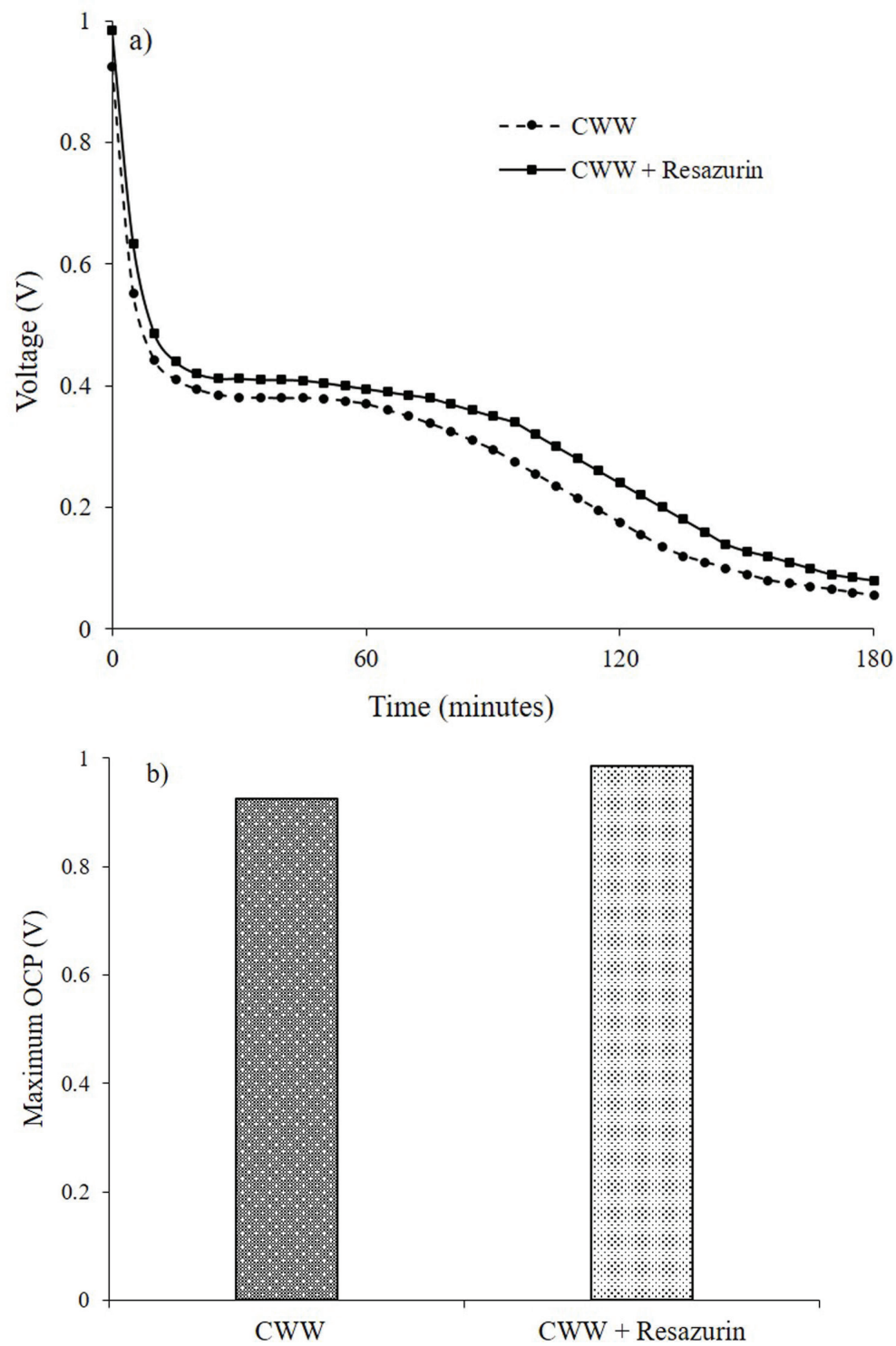

Fig. 4 - Effect of resazurin on the voltage output (a), and the open-circuit potential (b) of the $C W-M F C$ transfer rate of the electrogenic bacteria of biofilm to the anode electrode. The mediator mainly helps the non-nanowire forming bacteria and the bacteria of the biofilm that are distant from the electrode to donate electrons to the anode, and reduces the internal resistance of the MFC, thus increasing the performance of the CW-MFC for power production ${ }^{23}$. In a recently published report, authors found that the performance of MFC increased when mediator immobilized mixed culture was added to the pre-colonized biofilm in the anode chamber ${ }^{47}$.

\section{Effect of external nitrogen source on CW-MFC performance}

Nitrogen sources are important for the growth and multiplication of bacteria. Different nitrogenous compounds were examined to assess their impact on the CW-MFC performance. The performance of the CW-MFC increased when $1.0 \%$ peptone was supplied with CWW in the anode chamber; and a maximum voltage output of $0.390 \mathrm{~V}$ was observed (Fig. 5a). This was attributed to the supplementation of essential amino acids and other nitrogen compounds from peptone for the growth of exoelectrogens. It was observed that MFC having CWW with peptone was able to produce a maximum OCP of about $1.0 \mathrm{~V}$ (Fig. 5b). Additional peptone used with CWW also increased the dropout time of the voltage output. Sufficient addition of peptone as a nitrogen source to CWW (anode solution) had a positive impact on the performance of the CWMFC. A previous study has shown that peptone can be used as a substrate for electricity generation in $\mathrm{MFC}^{48}$. In case of the CW-MFC, peptone can be used as an additional substrate for enhancing the power output. However, yeast extract (voltage output, $0.366 \mathrm{~V}$ ), and urea (voltage output, $0.375 \mathrm{~V}$ ) showed no positive effect like peptone (Fig. 5a). The probable reason for not showing a positive effect on power generation was the production of toxic products by non-electrogenic bacteria, and the alteration of osmotic pressure when yeast extract and urea were added as nitrogen sources.

\section{Effect of external carbon source on CW-MFC performance}

Although CWW has all sorts of nutrients (carbon source, nitrogen source, proteins, lipids, vitamins, among others) for the growth and maturation of bacteria on an anode, a slight addition of an external carbon source can also increase the performance of the CW-MFC for electricity generation. The CWW contains mostly lactose as the carbon energy source with traces of other carbon sources ${ }^{38}$. It is found that the addition of $1.5 \%$ external glucose with CWW increases the overall voltage out- 


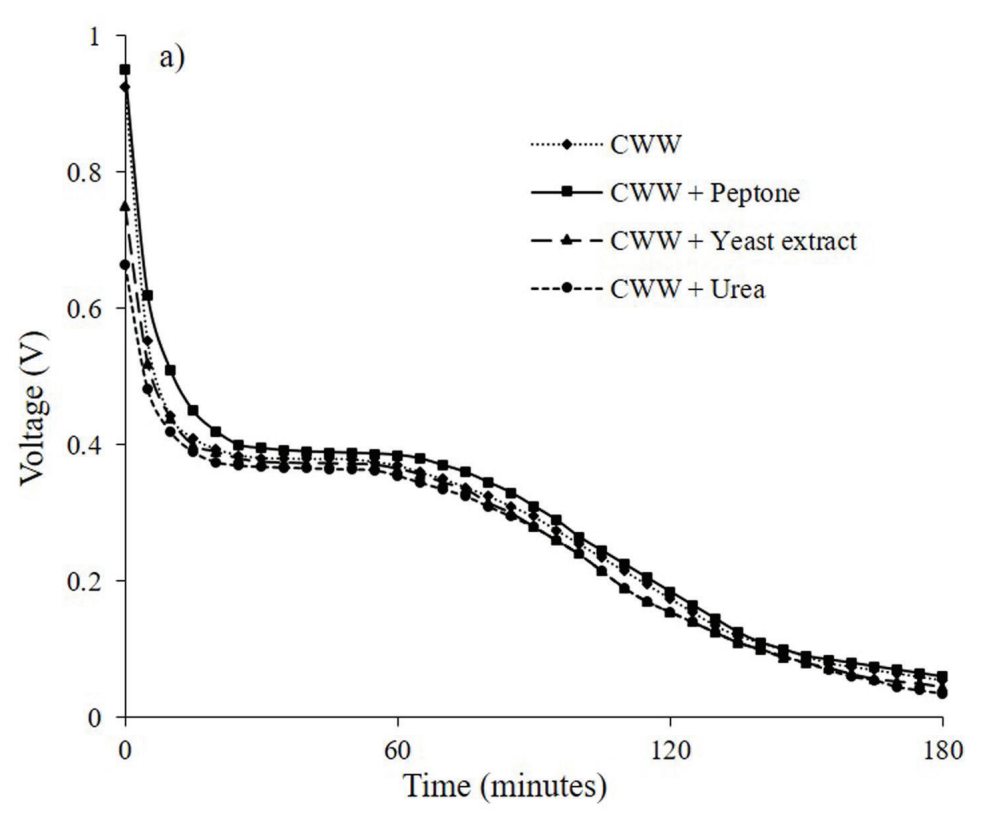

electrogenic activities, but other carbon sources (e.g., sucrose, starch) may cause overgrowth of other bacterial species. Thus, the addition of sucrose and starch into CWW may hamper the overall performance of the CW-MFC. More detailed investigations are needed for clarifying their role in the CWMFC, as well as for the optimization of their quantity for large-scale power production. A previous study found that the maximum voltage generated by MFC inoculated with Pseudomonas aeruginosa was higher for glucose containing synthetic wastewater than that for sucrose and starch ${ }^{13}$.

\section{Effect of anode surface area on CW-MFC performance}

Electrodes with various surface areas were used as the anodes to evaluate the effect of biofilm or the number of bacterial cells on the power gener-

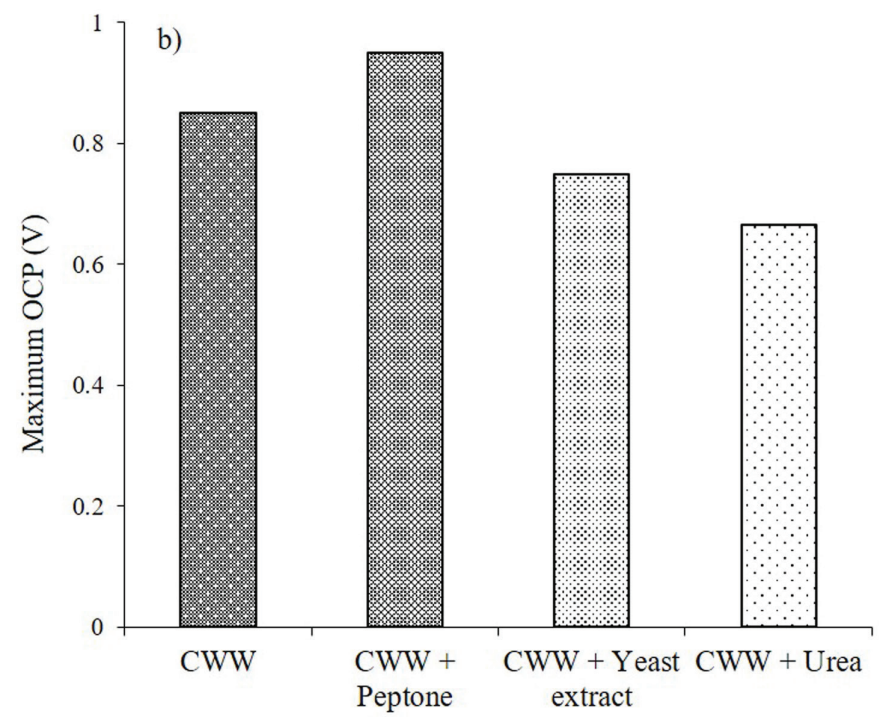

Fig. 5 - Effect of organic nitrogen sources on the voltage output (a), and the open-circuit potential (b) of the $C W-M F C$

put of the CW-MFC. In the present study, the maximum voltage output by the CW-MFC using CWW plus $1.5 \%$ glucose was $0.390 \mathrm{~V}$, slightly higher than that of the CW-MFC using CWW as sole the energy source (Fig. 6a). In contrast, other carbon sources, e.g., sucrose and starch caused no increase in overall voltage output. The CW-MFC produced maximum potentials using $1.5 \%$ sucrose and $1.5 \%$ starch with CWW of $0.372 \mathrm{~V}$ and $0.365 \mathrm{~V}$, respectively (Fig. 6a). Although the OCPs were almost similar for all carbon sources (Fig. 6b), the supplementation of $1.5 \%$ glucose had a positive impact on power production. The aforementioned results indicated that exoelectrogenic bacteria on the anode can accumulate a small amount of glucose for their
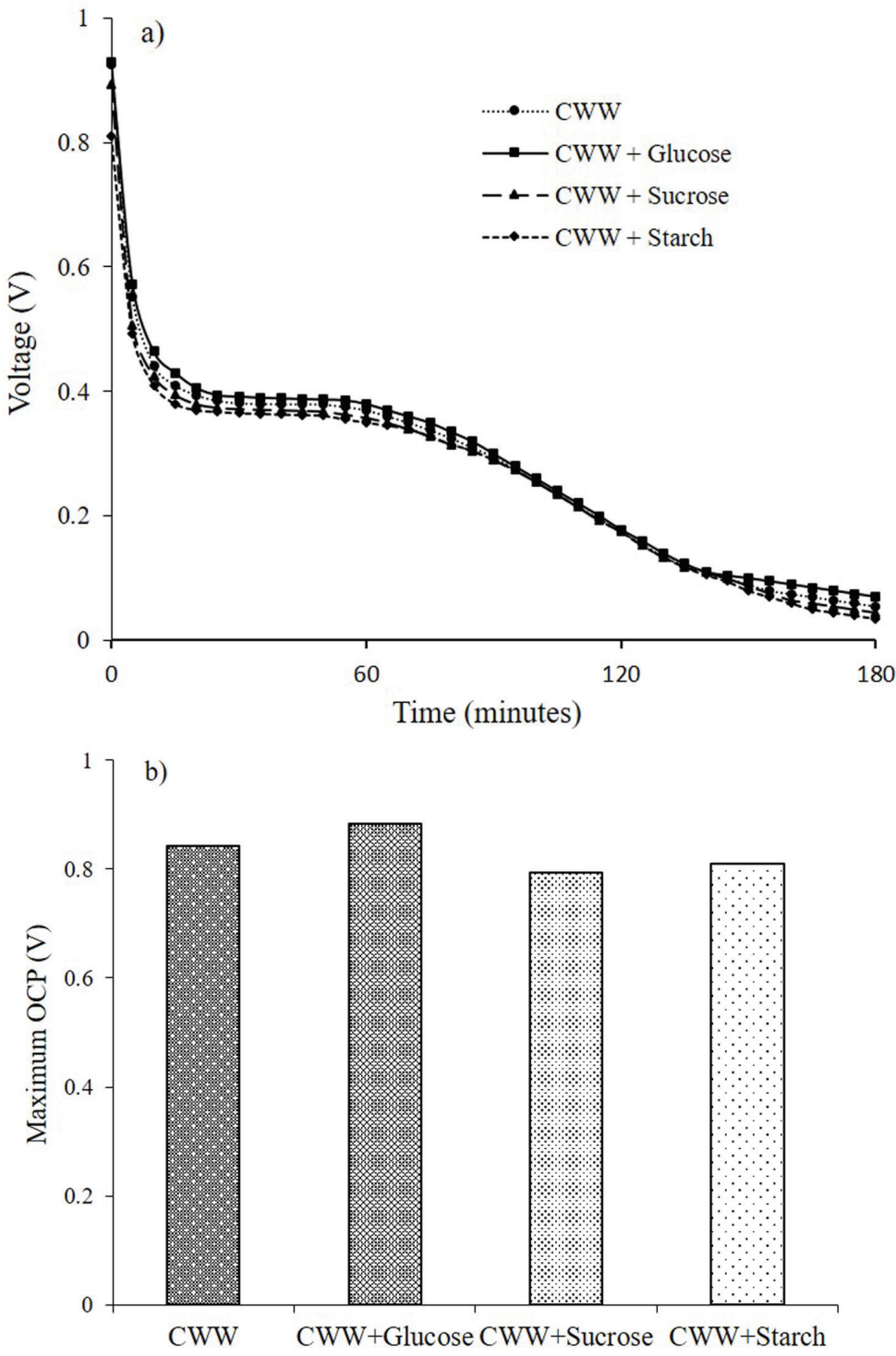

Fig. 6 - Effect of carbon sources on the voltage output (a), and the open-circuit potential (b) of the $C W-M F C$ 

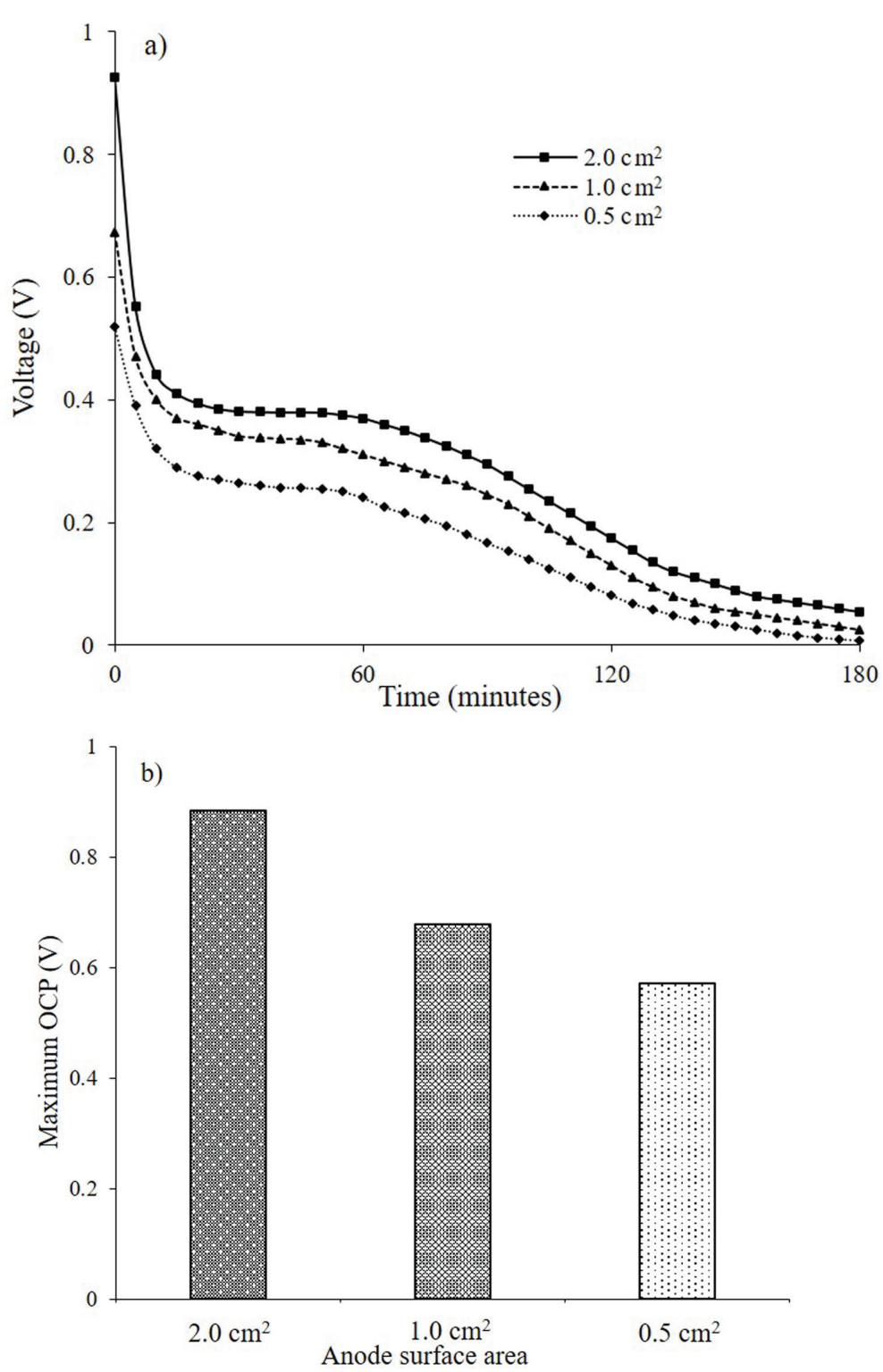

Fig. 7 - Effect of anode surface area on the voltage output (a), and the open-circuit potential (b) of the CW-MFC

ation of the CW-MFC. The results in this study showed that power output depended on the surface area. The voltages generated by the CW-MFCs with anode surface areas of $2 \mathrm{~cm}^{2}, 1 \mathrm{~cm}^{2}$ and $0.5 \mathrm{~cm}^{2}$ were $0.379 \mathrm{~V}, 0.338 \mathrm{~V}$, and $0.268 \mathrm{~V}$, respectively (Fig. 7a). The large surface area provided a large space for the bacterial cells to adhere and for the formation of biofilm, resulting in a huge number of electron transfers from the biofilm to the electrode, and consequently generating a high voltage output. These results emphasized that bacteria in the biofilm were responsible for electron generation and its transfer to anode and cathode through the outer circuit for current production. The OCPs for the anode surface areas of $2 \mathrm{~cm}^{2}, 1 \mathrm{~cm}^{2}$, and $0.5 \mathrm{~cm}^{2}$ were $0.85 \mathrm{~V}, 0.68 \mathrm{~V}$, and $0.57 \mathrm{~V}$, respectively (Fig. $7 \mathrm{~b}$ ).
This was because a large number of bacterial cells on the increased surface area were able to generate more electrons by their bio-catalytic activities from organic matter for transfer to the electrode. Since electron generation is associated with the metabolism and growth of bacteria, the biofilm on the anode had a direct proportional effect on the transfer of electrons to the anode. An electrode with a larger surface area for biofilm formation will exhibit a better electron transfer performance than smaller electrodes ${ }^{49}$. In a previous study, the parametric modelling of MFC exhibited that the anode surface area had an important role in the performance of MFC; and the larger anode surface area enhanced the current density of MFC by providing higher reaction rates in the anode ${ }^{50}$.

\section{Power generation and real application}

To evaluate power generated by the CW-MFC, the polarization and power density curves were constructed using the fixed variable external resistances ranging from $10000 \Omega$ to $10 \Omega$. The maximum power density and current density achieved by the CW-MFC were $7.18 \mathrm{~mW} \mathrm{~m}^{-2}$ and $35.75 \mathrm{~mA} \mathrm{~m}^{-2}$, respectively (Fig. 8). For the demonstration of real application, seven CW-MFCs were operated and connected in series with a 4 V LED strip having 6 LED lights. The OCP of each CW-MFC ranged from $0.9-1.05 \mathrm{~V}$ after one-hour operation in open circuit conditions (Table 1). Fluctuation in maximum OCP in each MFC was due to the defects during manual operation, as well as the growth, maturation, and efficiency for electron transfer rate of the biofilm on the anode electrode. The total OCP of seven CW-MFCs connected in series was $7.0 \mathrm{~V}$ witch was able to run a $4 \mathrm{~V}$ LED light strip for more than 3 hours (Fig. 9).

Table 1 -Open circuit potential (OCP) of $7 C W-M F C s$ and total OCP in series connection

\begin{tabular}{c|c|c}
\hline CW-MFC No. & $\begin{array}{c}\text { OCP (V) after 1 } \\
\text { hour operation }\end{array}$ & Total OCP (V) \\
\hline 1 & 0.984 & \\
2 & 1.050 & \\
3 & 0.939 & 7.0 \\
4 & 0.914 & \\
5 & 0.970 \\
6 & 0.940 \\
7
\end{tabular}




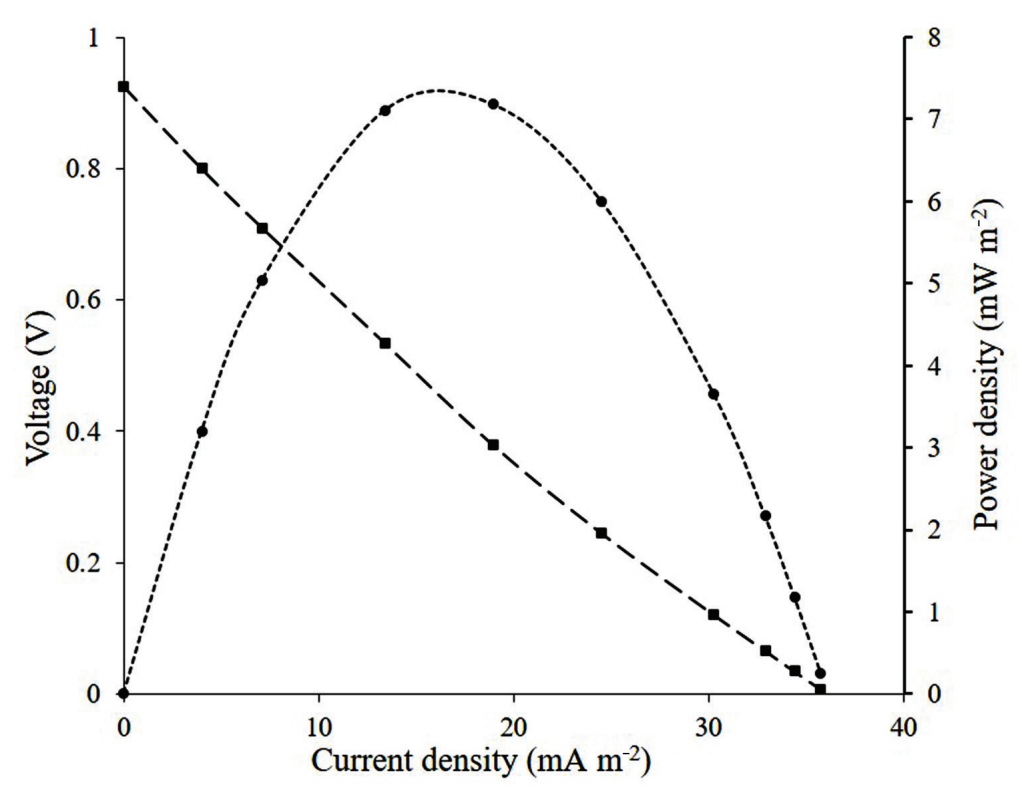

Fig. 8 - Polarization and power density curve of the $C W-M F C$

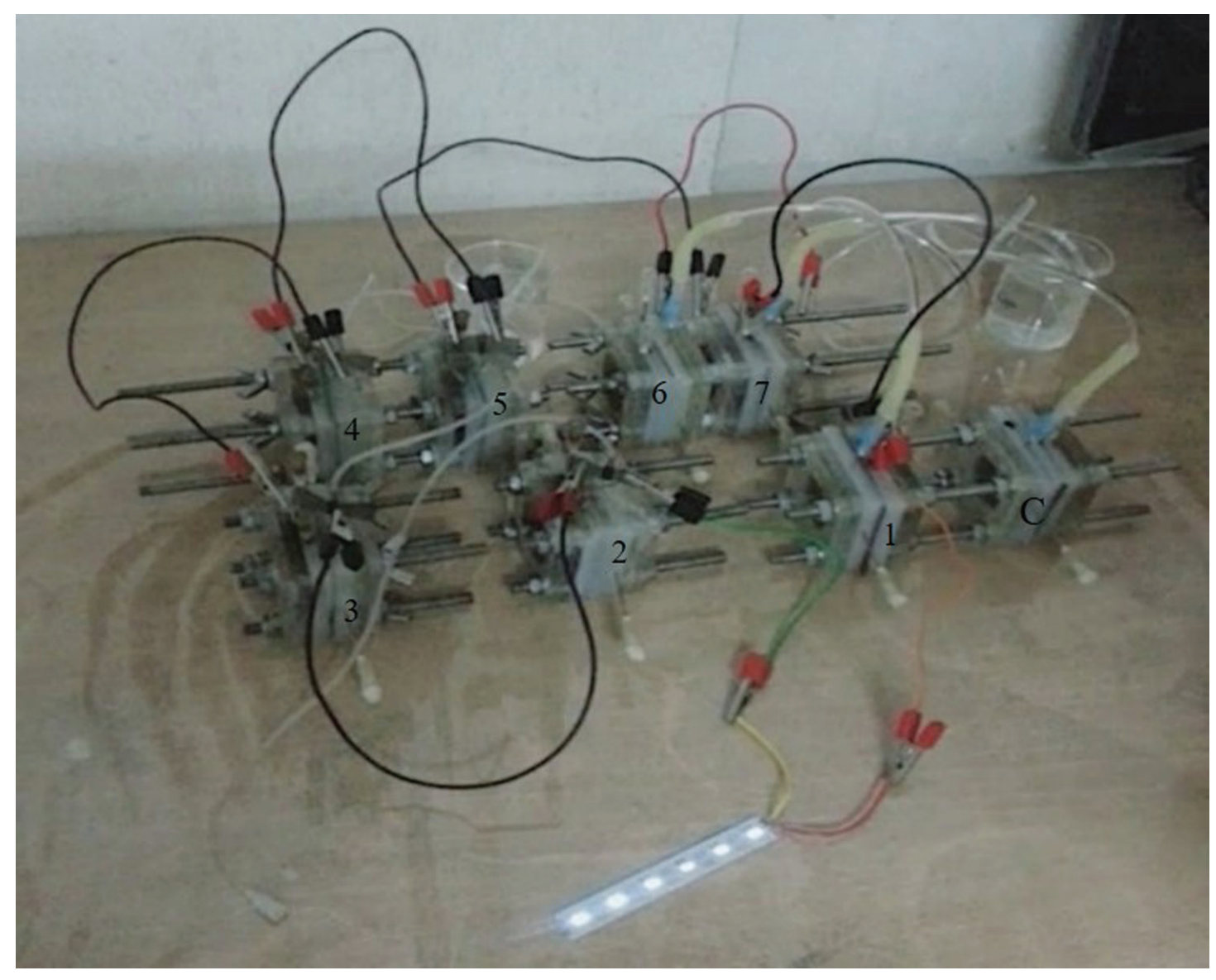

Fig. $9-A 4$ V LED light strip powered by seven CW-MFCs connected in series 


\section{Conclusions}

MFC is one of the renewable technologies for generating electricity from different domestic and industrial wastewaters. The present study showed that CW-MFC technique was able to produce electricity successfully from locally collected cheese whey wastewater. The power generated by seven serially connected CW-MFCs was capable of running a $4 \mathrm{~V}$ LED light strip for a few hours. It is expected that CW-MFC can be a promising technique for electricity generation from cheese whey wastewater only without the necessity of adding extra chemicals and energy.

\section{ACKNOWLEDGMENTS}

This research work has been funded by Rajshahi University Research Project, Grant number 1105/5/52/R.U./Science-06/16-17/36, the Faculty of Science, University of Rajshahi, Bangladesh.

\section{References}

1. Bentley, R. W., Global oil and gas depletion: An overview, Energy Pol. 30 (2002) 189.

doi: https://doi.org/10.1016/S0301-4215(01)00144-6

2. Dincer, I., Energy and environmental impacts: Present and future perspectives, Energy Sources 20 (1998) 427. doi: https://doi.org/10.1080/00908319808970070

3. Vidal-Amaro, J. J., Sheinbaum-Pardo, C., A transition strategy from fossil fuels to renewable energy sources in the Mexican electricity system, J. Sustain. Dev. Energy Water Environ. Syst. 6 (2018) 47. doi: https://doi.org/10.13044/j.sdewes.d5.0170

4. Gavira, M. O., Research and development financing in the renewable energy industry in Brazil, J. Sustain. Dev. Energy Water Environ. Syst. 2 (2014) 208.

doi: https://doi.org/10.13044/j.sdewes.2014.02.0017

5. Lewis, N. S., Toward cost-effective solar energy use, Science 315 (2007) 798.

doi: https://doi.org/10.1126/science.1137014

6. Kovacic, D., Kralik, D., Rupcic, S., Jovcic, D., Spajic, R., Tisma, M., Soybean straw, corn stover and sunflower stalk as possible substrates for biogas production in Croatia: A review, Chem. Biochem. Eng. Q. 31 (2017) 187. doi: https://doi.org/10.15255/CABEQ.2016.985

7. Manwell, J. F., Mc-Gowan, J. G., Rogers, A. L., Wind energy explained: Theory, design and application, John Wiley \& Sons, USA, 2009.

doi: http://ee.tlu.edu.vn/Portals/0/2018/NLG/Sach_Tieng_Anh.pdf

8. Zarfl, C., Lumsdon, A. E., Berlekamp, J., Tydecks, L., Tockner, $K$., A global boom in hydropower dam construction, Aquat. Sci. 77 (2015) 161.

doi: https://doi.org/10.1007/s00027-014-0377-0

9. Potter, M. C., Electrical effects accompanying the decomposition of organic compounds, Proceedings of the Royal Society of London. Series B, Containing Papers of a Biological Character 84 (1911) 260. doi: https://doi.org/10.1098/rspb.1911.0073
10. Lovley, D. R., Microbial fuel cells: Novel microbial physiologies and engineering approaches, Curr. Opin. Biotechnol. 17 (2006) 327. doi: https://doi.org/10.1016/j.copbio.2006.04.006

11. You, S. J., Zhao, Q. L., Jiang, J. Q., Zhang, J. N., Treatment of domestic wastewater with simultaneous electricity generation in microbial fuel cell under continuous operation, Chem. Biochem. Eng. Q. 20 (2006) 407. doi: https://doi.org/10.15255/CABEQ.2014.447

12. Mamani-Asqui, L. J., Peredo-Berlanga, L. N., Roque Rodriguez, F. J., Salazar-Banda, G. R., Vicia faba crop residues for sustainable electricity generation using a sludge-based microbial fuel cell, Chem. Biochem. Eng. Q. 34 (2020) 289. doi: https://doi.org/10.15255/CABEQ.2020.1857

13. Choudhury, P., Majumdar, R., Bandyopadhyaya, T. K., Comparative study between synthetic and dairy wastewaters in single chamber microbial fuel cell for power generation, J. Electrochem. Sci. Eng. 11 (2021) 279. doi: https://doi.org/10.5599/jese.1030

14. Huang, L., Logan, B. E., Electricity generation and treatment of paper recycling wastewater using a microbial fuel cell, Appl. Microbiol. Biotechnol. 80 (2008) 349. doi: https://doi.org/10.1007/s00253-008-1546-7

15. Xu, X., Zhao, Q. L., Wu, M. S., Removal and changes of sediment organic matter and electricity generation by sediment microbial fuel cells and amorphous ferric hydroxide, Chem. Biochem. Eng. Q. 28 (2014) 561. doi: https://doi.org/10.15255/CABEQ.2014.2029

16. Logan, B. E., Regan, J. M., Electricity-producing bacterial communities in microbial fuel cells, Trends Microbiol. 14 (2006) 512. doi: https://doi.org/10.1016/j.tim.2006.10.003

17. Logan, B. E., Exoelectrogenic bacteria that power microbial fuel cells, Nat. Rev. Microbiol. 7 (2009) 375. doi: https://doi.org/10.1038/nrmicro2113

18. Chae, K. J., Choi, M., Ajayi, F. F., Park, W., Chang, I. S., Kim, I. S., Mass transport through a proton exchange membrane (Nafion) in microbial fuel cells, Energy Fuels 22 (2007) 169. doi: https://doi.org/10.1021/ef700308u

19. Fang, C., Min, B., Angelidaki, I., Nitrate as an oxidant in the cathode chamber of a microbial fuel cell for both power generation and nutrient removal purposes, Appl. Biochem. Biotechnol. 164 (2011) 464. doi: https://doi.org/10.1007/s12010-010-9148-0

20. You, S., Zhao, Q., Zhang, J., Jiang, J., Zhao, S., A microbial fuel cell using permanganate as the cathodic electron acceptor, J. Power Sources 162 (2006) 1409. doi: https://doi.org/10.1016/j.jpowsour.2006.07.063

21. Nasirahmadi, S., Safekordi, A. A., Whey as a substrate for generation of bioelectricity in microbial fuel cell using $E$. coli, Int. J. Environ. Sci. Technol. 8 (2011) 823. doi: https://doi.org/10.1007/BF03326265

22. Ieropoulos, I. A., Greenman, J., Melhuish, C., Hart, J., Comparative study of three types of microbial fuel cell, Enzyme Microb. Technol. 37 (2005) 238. doi: https://doi.org/10.1016/j.enzmictec.2005.03.006

23. Park, D. H., Zeikus, J. G., Electricity generation in microbial fuel cells using neutral red as an electronophore, Appl. Environ. Microbiol. 66 (2000) 1292. doi: https://doi.org/10.1128/aem.66.4.1292-1297.2000

24. Vega, C. A., Fernandez, I., Mediating effect of ferric chelate compounds in microbial fuel cells with Lactobacillus plantarum, Streptococcus lactis, and Erwinia dissolvens, Bioelectrochem. Bioenerg. 17 (1987) 217. doi: https://doi.org/10.1016/0302-4598(87)80026-0 
25. Feng, Y., Wang, X., Logan, B. E., Lee, H., Brewery wastewater treatment using air-cathode microbial fuel cells, Appl. Microbiol. Biotechnol. 78 (2008) 873. doi: https://doi.org/10.1007/s00253-008-1360-2

26. He, Z., Minteer, S. D., Angenent, L. T., Electricity generation from artificial wastewater using an upflow microbial fuel cell, Environ. Sci. Technol. 39 (2005) 5262. doi: https://doi.org/10.1021/es0502876

27. Park, D., Zeikus, J., Impact of electrode composition on electricity generation in a single-compartment fuel cell using Shewanella putrefaciens, Appl. Microbiol. Biotechnol. 59 (2002) 58. doi: https://doi.org/10.1007/s00253-002-0972-1

28. Hays, S., Zhang, F., Logan, B. E., Performance of two different types of anodes in membrane electrode assembly microbial fuel cells for power generation from domestic wastewater, J. Power Sources 196 (2011) 8293. doi: https://doi.org/10.1016/j.jpowsour.2011.06.027

29. Wei, J., Liang, P., Huang, X., Recent progress in electrodes for microbial fuel cells, Bioresour. Technol. 102 (2011) 9335.

doi: https://doi.org/10.1016/j.biortech.2011.07.019

30. Oh, S. E., Logan, B. E., Proton exchange membrane and electrode surface areas as factors that affect power generation in microbial fuel cells, Appl. Microbiol. Biotechnol. 70 (2006) 162. doi: https://doi.org/10.1007/s00253-005-0066-y

31. Addi, H., Mateo-Ramírez, F., Ortiz-Martínez, V. M., Salar-García, M. J., Hernández-Fernández, F. J., Ríos, A. P. D., Godinez, C., Lotfi, E. M., Mahi, M. E., Blanco, L. J. L., Treatment of mineral oil refinery wastewater in microbial fuel cells using ionic liquid based separators, Appl. Sci. 8 (2018) 438. doi: https://doi.org/10.3390/app8030438

32. Larrosa-Guerrero, A., Scott, K., Head, I. M., Mateo, F., Ginesta, A., Godinez, C., Effect of temperature on the performance of microbial fuel cells, Fuel 89 (2010) 3985. doi: https://doi.org/10.1016/j.fuel.2010.06.025

33. Puig, S., Serra, M., Coma, M., Cabré, M., Balaguer, M. D., Colprim, J., Effect of $\mathrm{pH}$ on nutrient dynamics and electricity production using microbial fuel cells, Bioresour. Technol. 101 (2010) 9594.

doi: https://doi.org/10.1016/j.biortech.2010.07.082

34. Lefebvre, O., Tan, Z., Kharkwal, S., Ng, H. Y., Effect of increasing anodic $\mathrm{NaCl}$ concentration on microbial fuel cell performance, Bioresour. Technol. 112 (2012) 336. doi: https://doi.org/10.1016/j.biortech.2012.02.048

35. Pandit, S., Sengupta, A., Kale, S., Das, D., Performance of electron acceptors in catholyte of a two-chambered microbial fuel cell using anion exchange membrane, Bioresour. Technol. 102 (2011) 2736. doi: https://doi.org/10.1016/j.biortech.2010.11.038

36. Ni, H., Wang, K., Lv, S., Wang, X., Zhang, J., Zhuo, L., Li, $F$., Effects of modified anodes on the performance and microbial community of microbial fuel cells using swine wastewater, Energies 13 (2020) 3980. doi: https://doi.org/10.3390/en13153980

37. $F u, C$., $M a, F$., Optimization of electrochemical parameters in microbial fuel cell system based on Fuzzy-PID and CMAC neural network, J. Electrochem. Sci. Eng. 9 (2019) 135. doi: http://doi.org/10.5599/jese.636
38. Siso, M. G., The biotechnological utilization of cheese whey: A review, Bioresour. Technol. 57 (1996) 1. doi: https://doi.org/10.1016/0960-8524(96)00036-3

39. Kosikowski, F. V., Whey utilization and whey products, J. Dairy Sci. 62 (1979) 1149. doi: https://doi.org/10.3168/jds.S0022-0302(79)83389-5

40. Marwaha, S. S., Kennedy, J. F., Whey-pollution problem and potential utilization, Int. J. Food Sci. Technol. 23 (1988) 323. doi: https://doi.org/10.1111/j.1365-2621.1988.tb00586.x

41. Sindhuja, M., Padmapriya, S., Sudha, V., Harinipriya, S., Phase specific $\alpha-\mathrm{MnO}_{2}$ synthesis by microbial fuel cell for supercapacitor applications with simultaneous power generation, Int. J. Hydrog. Energy 44 (2019) 5389. doi: https://doi.org/10.1016/j.ijhydene.2018.08.123

42. Antonopoulou, G., Stamatelatou, K., Bebelis, S., Lyberatos, $G$., Electricity generation from synthetic substrates and cheese whey using a two-chamber microbial fuel cell, Biochem. Eng. J. 50 (2010) 10. doi: https://doi.org/10.1016/j.bej.2010.02.008

43. Kong, X., Sun, Y., Yuan, Z., Li, D., Li, L., Li, Y., Effect of cathode electron-receiver on the performance of microbial fuel cells, Int. J. Hydrog. Energy 35 (2010) 7224. doi: https://doi.org/10.1016/j.ijhydene.2010.03.106

44. Guerrero-Rangel, N., Garza, J. A. R., Garza-Garcia, Y., Rios-Gonzalez, L. J., Sosa-Santillan, G. J., Garza-Rodriguez, I. M., Martinez-Amador, S. Y., Rodriguez-Garza, M. M., Rodriguez-Martinez, J., Comparative study of three cathodic electron acceptors on the performance of medatiorless microbial fuel cell, Int. J. Electr. Power Eng. 4 (2010) 27. doi: https://doi.org/10.3923/ijepe.2010.27.31

45. Cai, J., Zheng, P., Mahmood, Q., Effect of cathode electron acceptors on simultaneous anaerobic sulfide and nitrate removal in microbial fuel cell, Water Sci. Technol. 73 (2016) 947. doi: https://doi.org/10.2166/wst.2015.570

46. Kumar, S. S., Basu, S., Bishnoi, N. R., Effect of cathode environment on bioelectricity generation using a novel consortium in anode side of a microbial fuel cell, Biochem. Eng. J. 121 (2017) 17. doi: http://doi.org/10.1016/j.bej.2017.01.014

47. Sharma, S. C. D., Li, J., Hu, A., Chang, C. C., Yu, C. P., Integration of pre-colonized and mediator immobilized mixed culture for the improvement of electricity production of microbial fuel cells, Eviron. Technol. Innov. 22 (2021) 101514. doi: https://doi.org/10.1016/j.eti.2021.101514

48. Heilmann, J., and Logan, B. E., Production of electricity from proteins using a microbial fuel cell, Water Environ. Res. 78 (2006) 531. doi: https://doi.org/10.2175/106143005X73046

49. Di Lorenzo, M., Scott, K., Curtis, T. P., Head, I. M., Effect of increasing anode surface area on the performance of a single chamber microbial fuel cell, Chem. Eng. J. 156 (2010) 40 . doi: https://doi.org/10.1016/j.cej.2009.09.031

50. Singh, A., Krishnamurthy, B., Parametric modeling of microbial fuel cells, J. Electrochem. Sci. Eng. 9 (2019) 311. doi: https://doi.org/10.5599/jese.671 